\title{
Co-infection of Primary Syphilis and HIV after a Single Exposure - a Case Report
}

\author{
Stamatina GELEKI, Eftychia PLATSIDAKI*, Christina ANTONIOU, Vasilios PAPARIZOS \\ ${ }^{1}$ Dermatology Department, Andreas Sygros Venereal and Skin Diseases Hospital, Athens, Greece \\ ${ }^{*}$ Correspondence: Eftychia Platsidaki, e-mail: platsidakieft@yahoo.com \\ UDC 616.98:578.828HIV]: 616.972 \\ DE GRUYTER
OPEN
}

\begin{abstract}
Human immunodeficiency virus type 1- infected patients with syphilis are among the most important transmitters of HIV-1 infection due to biological effects of genital ulcerations, and aggravation due to their continued risky behavior. The association between primary syphilis and acute HIV-1 co-infection is not well documented, and reports on isolated cases are raising special interest and indicate that this double primary co-infection may occur. We present a case of a 31-year-old man with no past medical history who presented with fever, papular rash on the face which lasted for a few days, and a single genital ulcer. He was diagnosed with primary syphilis and primary HIV-1 infection after a single exposure with an infected female sex worker. Male-to-female HIV transmission during vaginal intercourse is significantly more likely than female-to-male HIV transmission. However, high prevalence of sexually transmitted diseases among female sex workers contributed to high HIV transmission probability, as in our case.

As far as the available world literature is concerned, this is the first case of co-infection of primary syphilis and HIV.
\end{abstract}

\section{Key words}

Syphilis; Syphilis, Cutaneous; Syphilis Serodiagnosis; Sexually Transmitted Diseases; HIV; Disease Transmission, Infectious; Case Reports

Syphilis is one of the most prevalent infections in people $\checkmark$ living with HIV/AIDS (human immunodeficiency virus/acquired immune deficiency syndrome). According to a recent research which estimated the prevalence of sexually transmitted infections (STI) in this group, the reported rates of syphilis co-infection in HIV-infected individuals range from $1 \%-21 \%$ in North America to $2 \%-43 \%$ in Europe (1). An increased prevalence of syphilis all over the world has been reported in the past 10 years, particularly after the introduction of highly active antiretroviral therapy (HAART) for AIDS in 1996, which was followed by increase in unsafe anal sex in men who have sex with men (MSM) (2). In addition, sporadic unconnected outbreaks of heterosexually transmitted syphilis associated with commercial sex workers, migration, and partner swapping have been documented (3).
Currently, syphilis and HIV go hand in hand, since they affect similar subgroups, facilitate the acquisition of each other, and may aggravate the clinical course of both diseases. The main way of transmission is among high risk groups, such as men who have sex with men, sex workers and drug users (4).

\section{Case report}

A 31-year-old man of Asian origin was admitted with a week history of small painful ulcers of the soft palate, tongue erythema and a single well defined firm, painless ulcer on the penis with adjacent inguinal lymphadenopathy. He also had multiple erythematous facial papules. On admission he was febrile, dehydrated, with a cachectic appearance. He received oral antibiotics and antivirals in the last 24 hours with no improvement. 


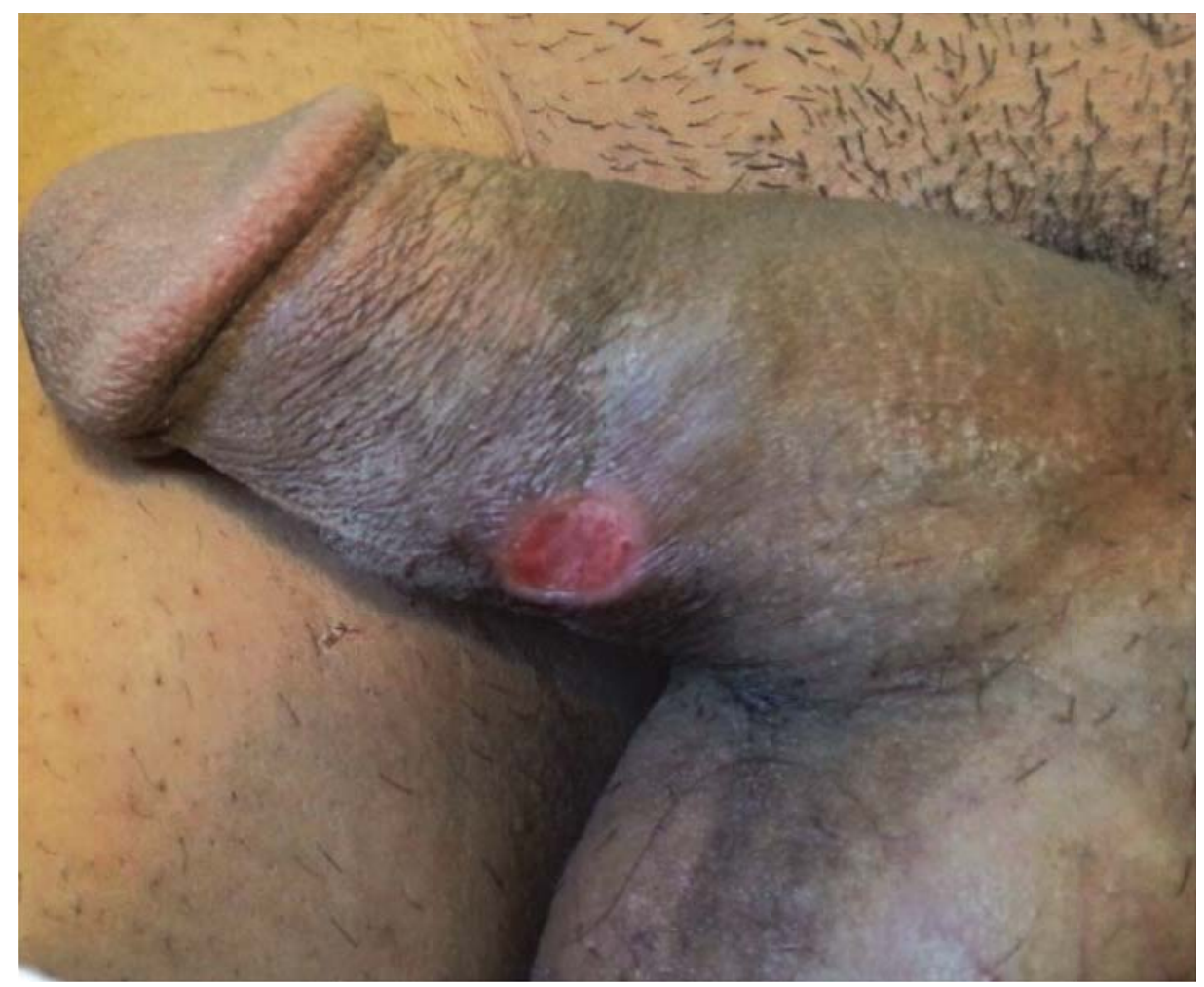

Figure 1. Penile lesion on admission

The patient had no significant medical history; he reported no history of recent travel, medication or illicit drug use. He had a single unprotected sexual intercourse (oral and vaginal sex) with a female illegal sex worker about 4 weeks before the onset of lesions. He claimed he did not have sex in the past three years.

Laboratory tests showed negative direct microscopy findings from the penile lesion for Treponema pallidum, a weakly positive VDRL test (Venereal Disease Research Laboratory), positive $T$. Pallidum enzyme immunoassay (EIA) for IgM and IgG and positive test results for Treponema pallidum particle agglutination (TP-PA) (Fujirebio, Belgium) with a titer $1: 2560$, indicating syphilis infection. Routine ELISA HIV antibody test (Vironostika, France) was positive, but Western-blot (Fujirebio, Belgium) which is the gold standard for the detection of antibodies to HIV-1 was negative, while lymphocytopenia with a CD4/CD8 ratio of 0.124 raised suspicion of an overlap between primary HIV and syphilis infection. The patient was successfully treated for syphilis with 2,4 millions of intramuscular benzathine penicillin
G. On a follow up visit after a month of treatment, VDRL test was negative, Western-blot turned out to be strongly positive; CD4 T lymphocyte count was 406 cells $/ \mathrm{mm}^{3}$ of blood (normally $500-1,200$ ), with a high total viral load of $140.000 / \mathrm{ml}$ of blood. Clinically, the genital ulcer resolved after a week of treatment, leaving an area of hyperpigmentation, and facial papules also disappeared within 3 weeks. The patient was diagnosed with primary co-infection of syphilis and HIV.

\section{Discussion}

A striking increase in the prevalence of concomitant human immunodeficiency virus (HIV) infection and syphilis, observed by clinicians and public health workers over the past decade, has renewed interest in the subject. The aforementioned differences in the prevalence of syphilis in HIV-infected individuals within different studies may be due to sampling, study design, diagnostic tests, or potentially temporal factors (5). Concomitant syphilis and HIV infection are particularly common among men who have 
sex with men (MSM) and sex workers (6). Several studies have reported the rate of HIV and syphilis co-infection as high as $50 \%(7,8)$. Moreover, in a crosssectional study conducted among HIV infected patients who attended the AIDS Outpatient Clinic in Victoria (Brazil), the prevalence of syphilis infection turned to be high as well, while syphilis infection was independently associated with male gender, history of male to male sex, current use of antiretroviral therapy, and history of syphilis infection (5). Nevertheless, to the best of our knowledge, there has been no report published in the world literature on primary co-infection of both syphilis and HIV after a single exposure.

Both syphilis and HIV typically present with primary lesions/symptoms between 2 to 6 weeks after exposure to Treponema pallidum and HIV1 , respectively. Although syphilis presentation in patients with HIV is largely similar to that in patients without HIV, differences in disease manifestation may be present $(9,10)$. Syphilis usually takes a more malignant course, although asymptomatic primary syphilis can also been seen (4). Serologic tests for syphilis in HIV-infected persons may be modified as well, showing extremely high titers, as in our patient.

Acute HIV (AHI) infection, with a duration of a few weeks to two months, is the earliest stage of HIV disease, when plasma HIV viremia can be detected, but before HIV antibodies can be measured (11-13). Forty to ninety percents of newly-infected persons may present with a clinical picture that represents a diagnostic challenge, usually described as "the worst flu ever" or "acute retroviral syndrome" (ARS) (13). Nonspecific symptoms called ARS or" primary HIV infection", are the body's natural response to the HIV infection and include fever, fatigue, pharyngitis, weight loss, night sweats, lymphadenopathy, myalgias, joint pain, headache, nausea and diarrhea. Rash or mucocutaneous ulcers can also be present (11). More specific symptoms, such as photophobia, and retroorbital pain may develop as well. Development of the classic mononucleosis-like symptoms coincides with high level viremia, as in our patient, and may last several days up to several weeks. Initial viremia has been reported to be as early as 4-11 days, while clinically detectable viremia may be more delayed (12). Leukopenia and/or thrombocytopenia, also seen in our patient, are frequently recovered and support the diagnosis. Formation of HIV-1-specific antibodies marks seroconversion; antibodies are generally detectable by week 3-12, most frequently 4 - 6 weeks after infection, although the window period may last up to $6-12$ months (12).

The diagnosis of acute HIV infection (AHI) becomes rather difficult concerning the fact that routine HIV antibody tests (rapid HIV test or conventional enzyme immunoassay EIA, or Western blot) will typically remain negative at the time of peak viremia and the onset of symptoms. Thus, additional virus-specific diagnostic tests with a window period $1-4$ weeks after exposure, such as viral load tests also called PCR (polymerase chain reaction) tests for plasma HIV load (HIV plasma RNA), or HIV p24 antigen assay (ELISA) are needed to detect HIV infection prior to the appearance of antibodies. The results of a viral load test are described as the number of copies of HIV RNA in a millilitre of blood. HIV p24 is a major protein that is part of HIV and is detectable $2-3$ weeks after infection - before antibodies are produced, but not really afterwards - and p24 levels only stay high for the next $1-2$ months. Assays that measure plasma HIV-1 load are more preferable because sensitivity of p24 antigen assay is time dependent, and p24 antigenemia may wane during AHI (12). Routine detection of HIV-1 plasma RNA by PCR is not currently approved by the US Food and Drug Administration for diagnosing HIV-1 infection unless history of recent high risk exposure (e.g. condom break with a known HIV-positive partner) and symptoms consistent with HIV seroconversion (fever, extreme tiredness, heavy "flu-like" illness etc.) are present, as in our patient (12). If it is positive, it must be confirmed with another test, either Western blot or antibody test that differentiates HIV-1 and HIV-2. Since EIA detects antibodies to HIV-1 and HIV-2, a routine confirmatory Western blot which is specific to HIV-1 is needed. When present alone, the HIV antibody test is considered to be indeterminate. This situation is frequently seen during seroconversion and should prompt correlation with the HIV-1 plasma RNA level, which was done in our patient. The diagnosis of primary HIV infection, also termed AHI, in our patient was based on the positive plasma HIV RNA test in conjunction with a indeterminate 
HIV antibody test, followed by a confirmatory Western blot at a subsequent point in time (13). On the other hand, the diagnosis of primary syphilis is easier, since sensitivity of the nontreponemal VDRL and rapid plasma reagin (RPR) tests are estimated to be $78-86 \%$ and treponemal tests such as fluuorescent treponemal antibody absorption (FTA-ABS) and TP-PA tests show a sensitivity of $84 \%$ for detecting primary syphilis (14).

All genital ulcer diseases, particularly syphilis, represent an important risk factor for the acquisition of HIV infection (15-17). Moreover, HIV-infected patients with syphilis may be among the most important transmitters of HIV infection due to continuous risky behavior, as well as biologic effects of genital ulcerations. Furthermore, in uncircumcised males, as in our patient, trauma and subsequently sexually transmitted infections are more likely to happen during intercourse on the area of highly vascular frenulum. Thus, circumcision can be considered an effective intervention for reducing HIV transmission by reducing the synergy that normally exists between HIV and other sexually transmitted infections (18).

Male-to-female HIV transmission during vaginal intercourse is significantly more likely than female-to-male HIV transmission (19). However, high prevalence of sexually transmitted diseases among female sex workers contributes to high HIV transmission probability, like in our case.

HIV-infected patients diagnosed with syphilis do not have specific regimens and should be treated for syphilis with the same regimens as non-HIV-infected patients. Our patient was treated in accordance with the recommended regimen for the treatment of primary and secondary syphilis in adults: a single dose 2.4 million units benzathine penicillin G, i.m. (4).

After antiretroviral therapy was introduced, most clinicians agreed that HIV-positive patients with low CD4 counts should be treated, but no consensus was gained as to whether to treat patients with high CD 4 counts. The only consensus was on treating patients with advanced immunosuppression (CD4

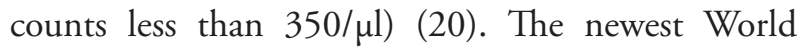
Health Organization Guidelines (dated September 30, 2015) recommend offering antiretroviral therapy (ART) to everyone living with HIV, at any CD4 cell count to reduce the risk of disease progression and for prevention of HIV transmission (21).

This report reviews a previously healthy male patient with primary syphilis and HIV-1, emphasing the importance of testing all persons with a new diagnosis of HIV for syphilis, and vice versa $(22,23)$. Additionally, it highlights the fact that syphilis agent may enhance the transmission of HIV. Aggressive control of genital ulcer diseases may offer one very feasible approach to reducing transmission of HIV infection.

\section{Conclusion}

As far as the world literature available to us is concerned, this is the first case of co-infection of primary syphilis and HIV.

\section{Abbreviations}

HIV - human immunodeficiency virus AIDS - acquired immune deficiency syndrome STI - sexually transmitted infections HAART - highly active antiretroviral therapy MSM - men who have sex with men VDRL - Venereal Disease Research Laboratory EIA - T. Pallidum enzyme immunoassay TP-PA - Treponema pallidum particle agglutination ELISA - enzyme-linked immunosorbent assay AHI - acute HIV infection PCR - polymerase chain reaction RNA - ribonucleic acid FTA-ABS - fluuorescent treponemal antibody absorption

\section{References}

1. Kalichman SC, Pellowski J, Turner C. Prevalence of sexually transmitted co-infections in people living with HIV/AIDS: systematic review with implications for using HIV treatments for prevention. Sex Transm Infect 2011;87:183-90.

2. Bjekić M, Šipetić S. An outbreak of early syphilis in patients registered at the City institute for skin and venereal diseases in Belgrade from 2010 to 2012: a case series of 86 patients. Serbian Journal of Dermatology and Venereology 2013;5(2):65-71.

3. Waugh M. Sexually transmitted infections: points of interest for 2006. Skinmed 2006;5(2):87-9.

4. Karp G, Schlaeffer F, Jotkowitz A, Riesenberg K. Syphilis and HIV co-infection. Eur J Intern Med 2009;20:9-13.

5. Callegari FM, Pinto-Neto LF, Medeiros CJ, Scopel CB, Page K, Miranda AE. Syphilis and HIV co-infection in patients 
who attend an AIDS outpatient clinic in Vitoria, Brazil. AIDS Behav 2014;18 Suppl 1:S104-9

6. Gao L, Zhang L, Jin Q. Meta-analysis: prevalence of HIV infection and syphilis among MSM in China. Sex Transm Infect 2009;85:354-8.

7. Paz-Bailey G, Meyers A, Blank S, Brown J, Rubin S, Braxton J, et al. A case-control study of syphilis among men who have sex with men in New York City: association with HIV infection. Sex Transm Dis 2004;31:581-7.

8. Wong W, Chew JK, Kent CK, Klausner JD. Risk factors for early syphilis among gay and bisexual men seen in an STD Clinic: San Francisco, 2002-2003. Sex Transm Dis 2005;32:458-63.

9. Buchacz K, Patel P, Taylor M, Kerndt PR, Byers RH, Holmberg $\mathrm{SD}$, et al. Syphilis increases HIV viral load and decreases CD4 cell counts in HIV-infected patients with new syphilis infections. AIDS 2004;18:2075-9.

10. Abdul Wahab A, Rahman MM, Mohammad M, Hussin S. Case series of syphilis and HIV co-infections. Pak J Med Sci 2013;29:856-8.

11. Von Mollendorf C. Acute HIV: what is new and do we treat. South Afr J HIV Med 2009; 10:17-21.

12. Kassutto S, Rosenberg ES. Primary HIV type 1 infection. Clin Infect Dis 2004;38:1447-53.

13. Dubrow R, Sikkema KJ, Mayer KH, Bruce RD, Julian P, Rodriguez $\mathrm{I}$, et al. Diagnosis of acute HIV infection in Connecticut. Conn Med 2009;73(6):325-31.

14. Calonge N. Screening for syphilis infection: recommendation statement. Ann Fam Med 2004;2:362-5.

15. Stamm WE, Handsfield HH, Rompalo AM, Ashley RL, Roberts PL, Corey L. The association between genital ulcer disease and acquisition of HIV infection in homosexual men. JAMA 1988;260:1429-33.

16. Kofoed K, Gerstoft J, Mathiesen LR, Benfield T. Syphilis and human immunodeficiency virus (HIV)-1 coinfection: influence on CD4 T-cell count, HIV-1 viral load, and treatment response. Sex Transm Dis 2006;33:143-8.

17. Adolf R, Bercht F, Aronis ML, Lunardi LW, Schechter M, Sprinz E. Prevalence and risk factors associated with syphilis in a cohort of HIV positive individuals in Brazil. AIDS Care 2012;24:252-8.

18. Szabo R, Short RV. How does male circumcision protect against HIV infection? BMJ 2000;320(7249):1592-4.

19. Mastro TD, Satten GA, Nopkesorn T, Sangkharomya S, Longini IM Jr. Probability of female-to-male transmission of HIV-1 in Thailand. Lancet 1994;343(8891):204-7.

20. Harrington M, Carpenter CC. Hit HIV-1 hard, but only when necessary. Lancet 2000;355(9221):2147-52.

21. World Health Organization. Guidelines: HIV. [cited 2015 Oct 27]. Available from: http://www.who.int/hiv/pub/ guidelines/en/

22. Zetola NM, Klausner JD. Syphilis and HIV infection: an update. Clin Infect Dis 2007;44:1222-8.

23. Lynn WA, Lightman S. Syphilis and HIV: a dangerous combination. Lancet Infect Dis 2004;4:456-66.

\section{Sifilis i HIV u primarnoj koinfekciji - prikaz slučaja}

\section{Sažetak}

Uvod. Sifilis predstavlja jednu od prevalentnijih infekcija među ljudima koji su inficirani virusom humane imunodeficijencije (engl. human immunodeficiency virus - HIV) i/ili žive sa sindromom stečene imunodeficijencije (engl. acquired immune deficiency syndrome - AIDS). Prevalencija koinfekcije uzročnikom sifilisa kreće se 1-21\% u Severnoj Americi, a 2-43\% u Evropi. Značajan porast učestalosti infekcije uzročnikom sifilisa registrovan je tokom poslednjih 10 godina u celom svetu, naročito posle uvođenja 1996. godine visoko aktivne retroviralne terapije za lečenje AIDS (engl. highly active antiretroviral therapy - HAART) i sve učestalijim upražnjavanjem nezaštićenog analnog seksa među muškarcima koji imaju seksualne odnose sa muškarcima (MSM). Štaviše, porastao je i broj slučajeva sifilisa nastao heteroseksualnim prenošenjem sa profesionalnih seksualnih radnika, promiskuitetnim ponašanjem i migracijama.

Prikaz slučaja. Tridesetjednogodišnji muškarac azijskog porekla, primljen je na bolničko lečenje zbog pojave bolnih ulceracija na mekom nepcu praćenih crvenililom jezika i jednog jasno ograničenog bezbolnog ulkusa sa tvrdim ivicama na penisu koji je pratila regionalna limfadenopatija. Po anamnestičkim podacima, promene su trajale nedelju dana. Istovremeno, na prijemu, pacijent je na licu imao multiple eritematozne papule, bio je febrilan, dehidriran i kahektičnog izgleda. Tokom $24 \mathrm{~h}$ pred prijem u bolnicu, započeo je uzimanje antibiotika, ali se stanje nije poboljšavalo uključujući i febrilnost.

Pacijent je negirao postojanje ozbiljnijih zdravstvenih problema u prošlosti, putovanja ili uzimanje lekova $\mathrm{u}$ poslednjem vremenskom periodu. Istakao je da je imao samo jedan nezaštićen seksualni odnos oralnim i vaginalnim putem sa ilegalnom seksualnom profesionalnom radnicom četiri nedelje pre pojave promena. Insistirao je na podatku da nije imao nijedan seksualni odnos tokom prethodne tri godine.

Relevantna laboratorijska ispitivanja su dala sledeće 
rezultate: negativan direktni mikroskopski pregled brisa uzetog sa ivica ulkusa na penisu na prisustvo Treponema pallidum; slabo pozitivan VDRL test (engl. Venereal Disease Research Laboratory); pozitivan Treponema pallidum IgM i IgG EIA test (engl. enzyme immunoassay); pozitivan Treponema pallidum TPPA aglutinacioni test (engl. Treponema pallidum particle agglutination assay) u titru 1/2 560, čime je dokazano prisustvo sifilistične infekcije; pozitivan rutinski ELISA (engl. enzyme linked immunoassay) test za dokazivanje prisustva antitela na HIV; negativan vestern blot test; prisustvo limfocitopenije sa CD4/ CD8 odnosom 0,124 što je pobudilo sumnju na preklapanje primarne HIV infekcije sa primarnom sifilističnom infekcijom.

Pacijent je uspešno lečen jednom intramuskularno primenjenom dozom benzatin penicilina $G$ od 2,4 milliona i.j. $\mathrm{Na}$ kontrolnom pregledu mesec dana kasnije dobijeni su sledeći rezultati: negativan VDRL test; vestern-blot test jako pozitivan; broj CD4+ T-llimfocita 406 ćelija $/ \mathrm{mm}^{3}$ krvi (referalno 500-1 200 ćelija $/ \mathrm{mm}^{3}$ ); PCR sa visokim brojem 140000 virusnih kopija/ml krvi. Ulkus na penisu je saniran nakon sedam dana od primenjene terapije, ostavljajući rezidualnu hiperpigmentaciju, dok su se papule na licu povukle nakon tri nedelje.

Kod pacijenta je postavljena dijagnoza primarne koinfekcije sifilisom i HIV-om na osnovu anamneze, kliničke slike i toka oboljenja kao i hronologije pozitivnih rezultata laboratorijskih ispitivanja.

Diskusija. S obzirom na to da od oba oboljenja obolevaju osobe unutar istih rizičnih populacija, da pospešuju međusoban razvoj i da mogu pogoršati kliničku sliku i tok jedno drugom, može se reći da u današnje vreme sifilis i HIV „idu“ paralelnim putem. Glavni put prenošenja sifilisa je unutar visoko rizičnih grupa koje čine muškarci koji imaju seks sa muškarcima, seksualne radnice i osobe sa bolestima zavisnosti. U najvećem broju slučajeva, kod osoba inficiranih HIV-om sifilis poprima maligniji tok, ali se mogu javiti i asimptomatski slučajevi primarnog sifilisa. Rezultati seroloških testova koji se koriste za postavljanje dijagnoze sifilisa kod HIV inficiranih osoba, takođe mogu biti modifikovani, kao što je to bio slučaj i kod pacijenta prikazanog u ovom radu.

Akutna HIV infekcija koja traje od nekoliko nedelja do dva meseca (u ovom vremenskom periodu u plazmi inficirane osobe može se dokazati HIV viremija ali ne i antitela protiv virusa), predstavlja najraniji stadijum HIV oboljenja. Oko 40-90\% novoinficiranih osoba HIV-om može u tom periodu razviti kliničku sliku koja sama po sebi predstavlja dijagnostički izazov, a opisuje se kao „akutni retrovirusni sindrom“ ili „primarna HIV infekcija“. U ovom stadijumu oboljenja, razvijaju se kod inficiranih osoba nespecifični znaci simptomi i klinički znaci koji predstavljaju izraz prirodne odbrane organizma od virusne infekcije: groznica, febrilnost, malaksalost, glavobolja, gušobolja, muka, povraćanje, dijareja, gubitak telesne težine, noćno znojenje, limfadenopatija, mijalgija, artralgije, ali i osipi po koži i mukokutane ulceracije. Specifičniji znaci mogu takođe biti prisutni i to u vidu fotofobije i retroorbitalnog bola. Razvoj klasičnih simptoma sličnih monomukleozi korelira sa visokim nivoom viremije kao što je to bio slučaj kod našeg pacijenta. Početna viremija može nastupiti već 4-11 dana od infekcije, dok se još laboratorijski ne može dokazati. Leukopenija i trombocitopenija, dokazana i kod našeg pacijenta, javlja se često i može olakšati dijagnozu. Formiranje HIV-1 specifičnih antitela označava serokonverziju i njihovo prisustvo može se dokazati 3-12 a najčešće 4-6 nedelja nakon infekcije, iako period prozora može trajati i 6-12 meseci.

Dijagnoza akutne HIV infekcije (AHI) otežava činjenica da rutiski testovi za dokazivanje HIV antitela kao što je EIA test ili vestern blot, ostaju negativni u vreme najveće viremije i početka prvih simptoma. Zato je potrebno u dijagnostički postupak uključiti virusspecifične dijagnostičke testove čiji periodi prozora traju 1-4 nedelje posle infekcije, sa ciljem dokazivanja HIV infekcije pre pojave antitela u serumu: PCR (engl. polymerase chain reaction) za određivanje HIV- RNA u plazmi tj. broja kopija HIV-RNA u mililitru krvi; HIV p24 antigen assay (ELISA). HIV p24 je glavni virusni protein koji se može dokazati 2-3 nedelje nakon infekcije - pre pojave antitela, ali ne i kasnije, s obzirom da njegov nivo ostaje visok samo u toku sledeća 1-2 meseca. Određivanje broja kopija HIV-RNA u mililitru krvi ima veću dijagnostičku vrednost, zato što je osetljivost p24 antigenskog testa zavisna od vremena: p24 antigenemija može nestati za vreme AHI.

Rutinsku detekciju HIV-1 RNA u plazmi nije odobrila FDA (US Food and Drug Administration) za dijagnozu HIV-1 infekcije osim u onim slučajevima 
u kojima postoje anamnezni podaci o skorašnjoj visoko rizičnoj ekspoziciji (npr. nezaštićeni seksualni odnos sa HIV pozitivnim partnerom), i/ili simptomi kompatibilni sa HIV serokonverzijom (temperatura, groznica, ekstremni umor, odnosno jače izraženi „akutni retrovirusni sindrom“), kao što je bilo i kod našeg pacijenta. Ukoliko je test pozitivan, mora biti potvrđen drugim testom, kojim se diferencira HIV1 od HIV-2, npr. vestern blot testom. S obzirom da EIA detektuje antitela na HIV-1 i HIV-2, rutinski test kojim potvrđujemo HIV infekciju jeste vestern blot. Kada je jedini pozitivan test EIA, kojim se određuju antitela, tada ga smatramo indeterminantnim. Ovo se često sreće za vreme serokoinverzije i promptno nameće potrebu za uključivanjem HIV-1 RNA u plazmi, što je i učinjeno kod našeg pacijenta.

Dijagnoza primarne HIV infekcije poznate i pod nazivom akutna HIV infekcija (AHI) postavljena je kod našeg pacijenta na osnovu pozitivnog nalaza HIV RNAu plazmi, u kombinaciji sa indeterminantnim EIA testom, koji su kasnije (hronološki sekvencionirano) potvrđeni vestern blot testom. $\mathrm{Na}$ drugoj strani, postavljanje dijagnoze primarnog sifilisa je značajno jednostavnije, s obzirom da se senzitivnost netroponemskih testova VDRL i RPR (engl. rapid plasma regain) kreće u rasponu 78-86\%, a da senzitivnost treponemskih testova FTAABS (fluuorescent treponemal antibody absorption) i TPPA iznosi oko $84 \%$ kada se radi o dijagnozi primarnog sifilisa.

Sve seksualno prenosive infekcije koje se manifestuju genitalnim ulceracijama, a naročito se to odnosi na sifilis, predstavljaju veoma značajan faktor rizika za prenošenje HIV infekcije. HIV inficirane osobe istovremeno obolele od sifilisa, s obzirom na kontinuirano rizično ponašanje i biološki potencijal genitalnih ulceracija, predstavljaju najvažnije prenosioce HIV infekcije. Štaviše, kod necirkumciziranih muškaraca, kao što je bio i naš pacijent, trauma za vreme seksualnog odnosa i veoma dobra vaskularizovanost frenuluma još više pospešuju prenos infekcije.

Prenos HIV infekcije sa muškarca na ženu za vreme vaginalnog odnosa je značajno češći nego sa žene na muškarca. Ipak, visoka prevalencija STI među profesionalnim seksualnim radnicama doprinosi visokom riziku od prenošenja HIV infekcije, kao što je to bio slučaj kod našeg pacijenta.

Pacijente inficirane HIV-om kod kojih je dijagnostikovan sifilis treba lečiti po istom režimu kao i neinficirane HIV pacijente: lečenje sprovedeno sa benzatin penicilinom $G$ 2,4 miliona jedinica, intramuskularno u jednoj dozi, po predloženom režimu za lečenje primarnog i sekundarnog sifilisa.

Posle uvođenja antiretroviralne terapije, većina kliničara se složila da pacijente ificirane HIV-om, koji imaju mali broj CD4+ limfocita u krvi, treba lečiti, ali konsenzus nije postignut oko stava da li lečenje treba započeti sa velikim brojem ovih ćelija. Jedini konsenzus koji je postignut jeste da treba lečiti pacijente sa uznapredovalom

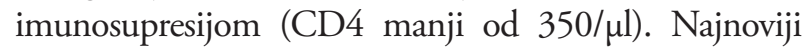
vodič Svetske zdravstvene organizacije (engl. World Health Organization guidelines dated September 30, 2015) podrazumeva da je antiretroviralna terapija potrebna svim osobama koje su inficirane virusom nezavisno od broja $\mathrm{CD} 4+$ limfocita. $\mathrm{Na}$ ovaj način smanjuje se progresija bolesti i rizik od transmisije.

Primarna HIV infekcija u koinfekciji sa primarnim sifilisom kod prethodno zdrave osobe, nastala nakon heteroseksualnog odnosa, ističe značaj testiranja na Treponema pallidum kod svih osoba sveže inficiranih HIV-om. Istovremeno ovaj slučaj potkrepljuje činjenicu da sifilis pospešuje transmisiju HIV infekcije i da samo agresivnom kontrolom svih oboljenja koja se manifestuju genitalnim ulceracijama možemo ući u borbu za smanjanje prenošenja HIV infekcije.

Zaključak. $\mathrm{Na}$ osnovu podataka iz nama dostupne svetske literature, ovo bi bio prvi objavljeni slučaj sifilisa i virusa humane imunodeficijencije u primarnoj koinfekciji.

\section{Ključne reči}

Sifilis; Kutani sifilis; Serodijagnouza sifilisa; Seksualno prenosive bolesti; HIV; Transmisija infektivnih bolesti; Prikazi slučajeva 